\title{
Preservation of nitrifying capacity and nitrate availability in waterlogged soils by radial oxygen loss from roots of wetland plants
}

Received: 28 April 1994

\begin{abstract}
The effects of radial $\mathrm{O}_{2}$ loss from roots on nitrification and $\mathrm{NO}_{3}^{-}$availability were studied. Plants of the flooding-resistant species Rumex palustris and the flooding-sensitive species Rumex thyrsiflorus were grown on drained and waterlogged soils with an initially high nitrifying capacity. Nitrate reductase activity in the plant leaves was used as an indicator of $\mathrm{NO}_{3}^{-}$availability to the plants. In a separate experiment these species were shown to have higher levels of nitrate reductase activity when $\mathrm{NO}_{3}^{-}$was added to the soils compared to when only $\mathrm{NH}_{4}^{+}$was provided. In drained soils nitrification was maintained and both plant species showed relatively high nitrate reductase activities in their leaves. In the waterlogged series planted with $R$. thyrsiflorus, nitrification was inhibited, $\mathrm{NH}_{4}^{+}$accumulated, and the plants grew less well compared to those on drained soils. In contrast, waterlogged soils planted with $R$. palustris had a redox potential high enough for $\mathrm{O}_{2}$ to be continuously replenished. Furthermore, the nitrifying capacity of these latter soils was maintained at a high level. $R$. palustris grew well and $\mathrm{NO}_{3}^{-}$must have been available to the plant, since a high level of nitrate reductase activity was observed in the leaves.
\end{abstract}

Key words Radial $\mathrm{O}_{2}$ loss $\cdot$ Nitrification $\cdot$ Waterlogging - Rumex thyrsiflorus - Rumex palustris . Nitrate reductase $\cdot$ Redox potential

\section{Introduction}

Many plants, especially calcicole species, prefer to take up $\mathrm{N}$ either as $\mathrm{NO}_{3}^{-}$or as a combination of $\mathrm{NO}_{3}^{-}$and $\mathrm{NH}_{4}^{+}$

W.M.H.G. Engelaar $(\bowtie)$ - C.W.P.M. Blom

Department of Ecology, University of Nijmegen,

Toernooiveld, 6525 ED Nijmegen, The Netherlands

J.C. Symens - H. J. Laanbroek

Department of Soil Biology,

Netherlands Institute for Ecological Research,

P.O. Box 40, 6666 ZG Heteren, The Netherlands
(Bogner 1968; Ellenberg 1977; Gigon and Rorison 1972). In natural soils, nitrification is probably the most important source of $\mathrm{NO}_{3}^{-}$. This oxidation of $\mathrm{NH}_{4}^{+}$via $\mathrm{NO}_{2}^{-}$to $\mathrm{NO}_{3}^{-}$is generally performed in two separate steps by chemolithotrophic nitrifying bacteria (Watson et al. 1989). The process of nitrification depends strongly on the $\mathrm{O}_{2}$ status of the environment because of the $\mathrm{O}_{2}$ dependency of the $\mathrm{NH}_{4}^{+}$-oxidizing enzyme, ammonium mono-oxygenase (Belser 1979). Upon waterlogging, the rate of diffusion of $\mathrm{O}_{2}$ into the soil decreases sharply (Armstrong 1979), whereas the $\mathrm{O}_{2}$ demand by the soil is maintained by the activity of plant roots and soil organisms. Hence anoxic conditions will occur (Ponnamperuma 1984). At this point nitrification will no longer take place and $\mathrm{NH}_{4}^{+}$accumulates (Laanbroek 1990).

The ability of certain plants to survive in these anoxic soils is generally increased by the presence of aerenchyma in their roots (Justin and Armstrong 1987; Laan et al. 1989 a). Radial $\mathrm{O}_{2}$ loss from aerenchymatous roots to the rhizosphere creates a small sheet of oxidized substrate around the root in an otherwise reduced environment (Laan et al. 1989b). Possibly, in this sheet the nitrifying population is still active, providing the plant with $\mathrm{NO}_{3}^{-}$. Both et al. (1992) found a larger nitrifying population in the oxidized rhizosphere of Glyceria maxima compared to the reduced bulk soil. However, in a previous experiment we observed no stimulation of nitrification by the flooding-resistant Rumex palustris species, which contains aerenchyma in its roots, under waterlogged conditions (Engelaar et al. 1991). We found that $\mathrm{NH}_{4}^{+}$and not $\mathrm{O}_{2}$ was probably limiting the activity of the nitrifying bacteria in the rhizosphere of this Rumex sp.

The aim of the present study was to investigate whether the nitrifying capacity of a waterlogged soil can be maintained by the presence of a plant species with aerenchymatous roots, provided that $\mathrm{NH}_{4}^{+}$is not a limiting factor. The experiment was performed with $R$. palustris, a flooding-resistant and $\mathrm{O}_{2}$-releasing species that forms aerenchymatous laterals under waterlogged conditions (Laan et al. 1989a; Voesenek et al. 1989), and $R$. thyr- 
siflorus a flooding-sensitive, non- $\mathrm{O}_{2}$-releasing species (Laan et al. 1989; Blom et al. 1990).

\section{Materials and methods}

Two experiments were performed. In the first experiment the use of nitrate reductase activities as a measure of $\mathrm{NO}_{3}^{-}$availability, as suggested previously (Uhel et al. 1989; Langelaan and Troelstra 1992), was validated for the two species studied. In the second experiment the positive effect of a flooding-resistant plant species on nitrification capacity and $\mathrm{NO}_{3}^{-}$availability in a flooded soil was investigated.

Seeds of $R$. palustris and $R$. thyrsiflorus were collected from floodplains in the Rhine delta, near Nijmegen, The Netherlands. After removal of the perianth, the seeds germinated on moist filter paper in Petri dishes, at a temperature of $10 \% 27^{\circ} \mathrm{C}$ with a $12 \mathrm{~h}$ night $/ 12 \mathrm{~h}$ day.

Nitrate reductase activity as a measure of $\mathrm{NO}_{3}^{-}$availability

Sixty-three light-proof plastic pots were prepared for each species. They were filled with $500 \mathrm{~g}$ air-dried, sieved (mesh size $2 \mathrm{~mm}$ ), calcareous river sand $\left[\mathrm{pH}\left(\mathrm{H}_{2} \mathrm{O}\right) 7.7\right]$ low in organic matter, collected from floodplains in the Rhine delta (Bemmel, The Netherlands). Each pot was supplied with $0.86 \mathrm{mmol} \mathrm{KH}_{2} \mathrm{PO}_{4}, 0.63 \mathrm{mmol}$ $\mathrm{K}_{2} \mathrm{SO}_{4}, 0.36 \mathrm{mmol} \mathrm{MgSO}_{4} \cdot 7 \mathrm{H}_{2} \mathrm{O}, 10 \mu \mathrm{mol}$ Fe-ethylenediaminedi(o-hydroxyphenyl acetic acid) and $4.2 \mathrm{mmol} \mathrm{N}$. The $\mathrm{N}$ was added as $\mathrm{NaNO}_{3}, \mathrm{NH}_{4} \mathrm{NO}_{3}$ or $\left(\mathrm{NH}_{4}\right)_{2} \mathrm{SO}_{4}$, each form to 21 pots. In the case of $\left(\mathrm{NH}_{4}\right)_{2} \mathrm{SO}_{4}$ half the $\mathrm{N}$ was applied at the start and the other half after 2 weeks. To all pots $5 \mathrm{mg}$ dicyandiamide, a nitrification inhibitor (Amberger 1986), was added. Analyses of soil mineral N at the end of a control experiment without plants showed that the dicyandiamide maintained its inhibitor action throughout the entire experimental period. The sand in the pots was brought to $60 \%$ water-holding capacity by adding $156 \mathrm{ml}$ demineralized water. One seedling of either $R$. palustris or $R$. thyrsiflorus was planted in each pot and the pots were placed in growth chambers with a day period of $16 \mathrm{~h}$, a photosynthetic photon flux density of $200 \pm 20 \mu \mathrm{E}$ $\mathrm{s}^{-1} \mathrm{~m}^{-2}$, and a temperature of $25^{\circ} \mathrm{C}$. At night, the temperature dropped to $15^{\circ} \mathrm{C}$. Relative humidity was kept constant at $55-70 \%$.

After 5 weeks, the nitrate reductase activity was determined 1 , 5,10 , and $14.5 \mathrm{~h}$ after the start of the light period and $0.5,4$, and $7 \mathrm{~h}$ after the start of the dark period. At each sampling time three plants per species were sampled, and the analyses were carried out in triplicate for each plant, on the youngest two or three fully developed leaves. The method used was a modification of the assay described by Jaworski (1971). The leaves were separated from the shoot, combined for each plant, and cut into segments of $0.5 \times 0,5 \mathrm{~cm}$ after removal of the nerve. Between 100 and $200 \mathrm{mg}$ of these segments was placed in 25 -ml flasks wrapped in aluminium foil, containing $4 \mathrm{mI} 0,25 \mathrm{M}$ phosphate buffer ( $\mathrm{pH} 7.8$ ) with chloramphenicol $(0.5 \mathrm{mg} / \mathrm{ml})$. After two $1-\mathrm{min}$ periods of vacuum infiltration, $1 \mathrm{ml} 0.2 \mathrm{M} \mathrm{KNO}_{3}$ solution containing 1-propanol $(75 \mu \mathrm{l} / \mathrm{ml})$ was added, and the flasks were sealed with a rubber stopper. Samples of $0.4 \mathrm{ml}$ were taken after 30 and $60 \mathrm{~min}$ of incubation at $30^{\circ} \mathrm{C}$ in a shaker $(60 \mathrm{rpm})$. The $\mathrm{NO}_{2}^{-}$accumulation was measured colorimetrically using a photospectrometer (Vitatron). Since the incubation was performed in the dark, $\mathrm{NO}_{2}^{-}$reduction to $\mathrm{NH}_{4}^{+}$ was inhibited (Beevers and Hageman 1969).

Nitrification and $\mathrm{NO}_{3}^{-}$availability in waterlogged soils

\section{Experimental design}

A series of 50 glass beakers $(600 \mathrm{ml})$ were filled with $704 \mathrm{~g}$ moistened soil. This soil consisted of five parts (dry weight) Bemmel sand and one part (dry weight) of the upper $5 \mathrm{~cm}$ of an extensively used, calcareous, sandy, grassland soil $\left[\mathrm{pH}\left(\mathrm{H}_{2} \mathrm{O}\right) 7.6\right]$, both sieved (mesh size $2 \mathrm{~mm}$ ). The grassland soil had been collected from floodplains of the Yssel (Brummen, The Netherlands). The Brummen soil was used as an inoculum of nitrifying bacteria and had been collected within 2 weeks of the start of the experiment. The pots contained $104 \mathrm{~g}$ water, bringing the dry soil to $60 \%$ water-holding capacity. All pots were wrapped with aluminium foil to make them lightproof. One seedling of either $R$. palustris or $R$. thyrsiflorus, with two fully developed leaves, was planted in each of the 50 pots. Nutrition was added to the pots as a modified Hoagland solution (Hoagland and Arnon 1950), $\mathrm{NO}_{3}^{-}$being replaced by $\mathrm{NH}_{4}^{+}$in combination with $\mathrm{SO}_{4}^{2-}$. This solution was added in exponentially increasing quantities, once a week, until week 7 . From that time onwards the maximum weekly dose was applied, comprising (per pot) $2.24 \mathrm{mmol} \mathrm{NH}_{4}^{+}, 0.28 \mathrm{mmol} \mathrm{H} \mathrm{PO}_{4}^{-}, 0.84 \mathrm{mmol} \mathrm{K}{ }^{+}, 0.14 \mathrm{mmol}$

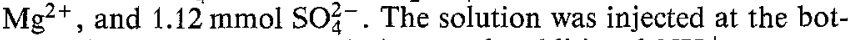
tom of the pot. From week 4 onwards additional $\mathrm{NH}_{4}^{+}$was supplied once a week, at $1,1.5$, and $2 \mathrm{mmol}$ per pot in weeks $4+5,6+7$, and $8+9$, respectively. The soils were kept at a constant moisture content by daily watering with demineralized water.

By week 4 , the plants had become large enough for the first sampling. Five plants of each species were sampled. Half the remaining pots were waterlogged at this time, taking care that the shoots stayed out of water. Another five drained and five waterlogged pots were sampled for each species in weeks 6 and 10. The youngest fully developed leaves were removed from the plants and used for analyses of nitrate reductase activity. Afterwards, the shoots, roots, soil, and, for the waterlogged pots, the water phase were separated. The shoots and roots were washed with tap water.

\section{Chemical analyses}

We analyzed several parameters as indicators of the three basic components of nitrification, $\mathrm{O}_{2}, \mathrm{NH}_{4}^{+}$, and an active nitrifying population. Any $\mathrm{NO}_{3}^{-}$produced was checked by measuring the $\mathrm{NO}_{3}^{-}$ content of the soil and by using the nitrate reductase activity of the leaves as an indicator of $\mathrm{NO}_{3}^{-}$uptake by the plants.

To measure the redox potential, four pots of each plant species, two waterlogged and two drained, were provided with a platinum electrode in week 4 . The electrode consisted of a PVC shaft with a platinum rod at the end (10 $\mathrm{mm}$ long, $1.5 \mathrm{~mm}$ in diameter) and was placed at the side of the pot $2-5 \mathrm{~cm}$ above the bottom. From this time onwards the redox potentials of the soils were measured regularly with this platinum electrode, a reference electrode $\left(\mathrm{Hg} / \mathrm{HgCl}_{2} /\right.$ saturated $\mathrm{KCl}$, Metrohm, type 60701.100), and a $\mathrm{mV}$ meter (Metrohm, type E 488).

To measure the dry weight of plants and soils, the roots, shoots, and $10 \mathrm{~g}$ of moist, homogenized soil per pot were dried separately for $24 \mathrm{~h}$ at $70^{\circ} \mathrm{C}$.

Soil extracts for mineral $\mathrm{N}$ measurements were prepared by shaking $50 \mathrm{ml} 1 \mathrm{M} \mathrm{KCl}$ solution and $10 \mathrm{~g}$ moist soil $(100 \mathrm{rpm})$ for $2 \mathrm{~h}$ at $20^{\circ} \mathrm{C}$. After centrifugation ( $5 \mathrm{~min}, 10000 \mathrm{rpm}$ ), $\mathrm{NH}_{4}^{+}$and $\mathrm{NO}_{3}^{-}$concentrations were determined in the supernatant using a Technicon Traacs 800 autoanalyzer. The mineral $N$ concentration in the water phase of the waterlogged pots was also determined after centrifugation, and added to the mineral $\mathrm{N}$ content of the corresponding soils.

To measure the nitrifying capacity of the soil, accumulations of $\mathrm{NO}_{2}^{-}$and $\mathrm{NO}_{3}^{-}$were measured in $250-\mathrm{ml}$ flasks, containing $40 \mathrm{~g}$ moist soil, $0.2 \mathrm{~g} \mathrm{CaCO}_{3}$, and $100 \mathrm{ml}$ medium, over a 6 -h period. The medium contained $2.5 \mathrm{mM}\left(\mathrm{NH}_{4}\right)_{2} \mathrm{SO}_{4}$ and $1 \mathrm{mM} \mathrm{P}$ buffer (pH 7.5) shaken at $150 \mathrm{rpm}$ and $25^{\circ} \mathrm{C}$. One-milliliter samples were taken from the flasks after 0.5 and $6 \mathrm{~h}$ of incubation and $\mathrm{NO}_{2}^{-}$and $\mathrm{NO}_{3}^{-}$concentrations were measured as described above. Preliminary experiments had demonstrated a linear production of $\mathrm{NO}_{3}^{-}$ and $\mathrm{NO}_{2}^{-}$during this 5.5 -h period. The assay for nitrate reductase activity was the same as in the first experiment. As a result of that experiment, samples were taken $4 \mathrm{~h}$ after the start of the light peri- 
od. Depending on the available biomass, one to three replicates were measured per plant.

\section{Statistical analysis}

Differences between treatments and sample times within one plant species were analyzed by means of the Wilcoxon two-sample test (Sokal and Rohlf 1981).

\section{Results}

Nitrate reductase activity as a measure of $\mathrm{NO}_{3}^{-}$availability

$R$. palustris showed a significantly higher nitrate reductase activity at all times of day when $\mathrm{N}$ was supplied as either $\mathrm{NO}_{3}^{-}$or a combination of $\mathrm{NH}_{4}^{+}$and $\mathrm{NO}_{3}^{-}$than when only $\mathrm{NH}_{4}^{+}$was added (Fig. 1). The same effect was observed in $R$. thyrsiflorus from $1 \mathrm{~h}$ before to $10 \mathrm{~h}$ after the start of the light period. On the basis of these results, the sampling time for the waterlogging experiment was set at $4 \mathrm{~h}$ after the start of the light period, with basic values $\left(\mathrm{NH}_{4}^{+}\right.$addition only) of approximately $2 \mu \mathrm{mol} \mathrm{NO} \mathrm{N}_{3}^{-}$ per $\mathrm{g}$ dry weight per hour for both species.

\section{Nitrification and nitrate availability} in waterlogged soils

The redox potentials measured in the soils are shown in Fig. 2. Differences between duplicate measurements in

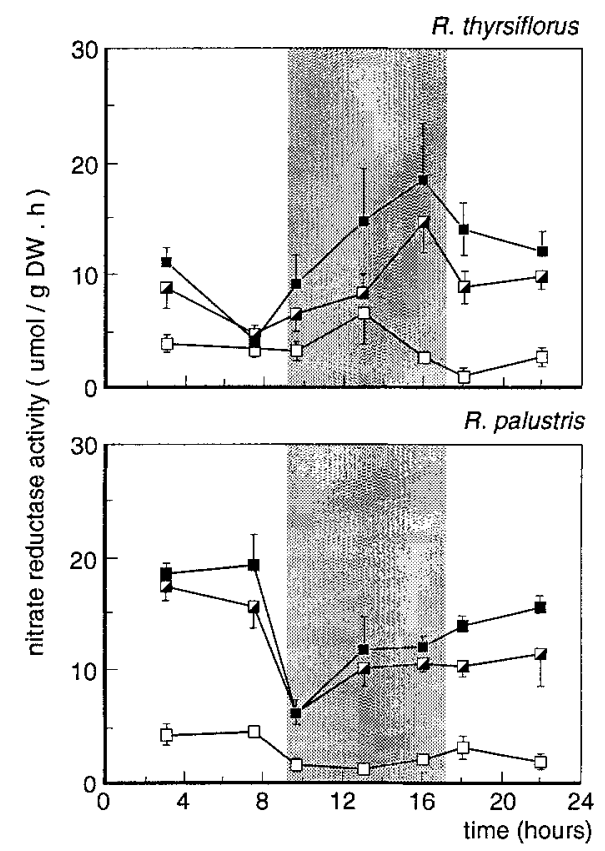

Fig. 1 Mean leaf nitrate reductase activities ( $\pm \mathrm{SD}, n=3)$ of Rumex thyrsiflorus and $R$. palustris plants supplied with either $\mathrm{NaNO}_{3}(\boldsymbol{\square}), \mathrm{NH}_{4} \mathrm{NO}_{3}(\boldsymbol{Z})$, or $\left(\mathrm{NH}_{4}\right)_{2} \mathrm{SO}_{4}(\square)$ throughout a 24-h period. The grey area represents the dark period. $D W$ dry weight

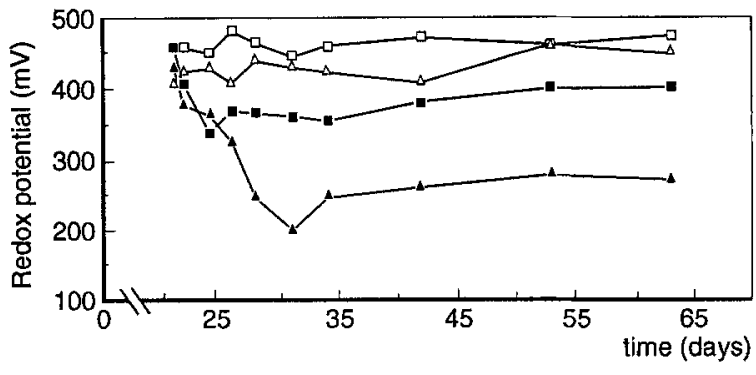

Fig. 2 Redox potentials in well drained (open symbols) and waterlogged (closed symbols) soils planted with either Rumex thyrsiflorus (triangles) or $R$. palustris (squares). Waterlogging started on day 21. Means of two replicates are shown

any one series ranged from 5 to $50 \mathrm{mV}$. Both well drained series remained at a constant value of approximately $450 \mathrm{mV}$ throughout the experiment. Upon waterlogging, the soils with either species showed an initial reduction of the redox potential. Soils with $R$. thyrsiflorus reached a constant value of $250 \mathrm{mV}$ after 28 days, but soils with $R$. palustris remained constant at a higher potential, $350-390 \mathrm{mV}$, from day 25 onwards.

All plants survived, except for one $R$. thyrsiflorus of the waterlogged series. The waterlogged $R$. thyrsiflorus plants produced significantly less shoot biomass by week 6 and less root and shoot biomass after week 10 compared to the plants with better drainage (Fig. 3). In week 6 , the waterlogged $R$. palustris plants also had less biomass compared to the plants with better drainage but by week 10 the waterlogged plants had produced the largest biomass.

As shown in Table 1, $\mathrm{N}$ was available in every soil, either as $\mathrm{NH}_{4}^{+}$or $\mathrm{NO}_{3}^{-}$, throughout the experiment. In all well drained soils $\mathrm{NO}_{3}^{-}$was the predominant $\mathrm{N}$ form. Upon waterlogging $\mathrm{NH}_{4}^{+}$became the most important $\mathrm{N}$ form in the soil for both plant species. In contrast to waterlogged soils planted with $R$. thyrsiflorus, $\mathrm{NO}_{3}^{-}$was still present in week 6 in the waterlogged soils planted with $R$. palustris and far less $\mathrm{NH}_{4}^{+}$accumulated in these soils towards the end of the experiment. The nitrifying capacity of the well drained soils increased from week 4 to week 6 and then remained fairly constant (Fig. 4). The major difference between the two species occurred in the waterlogged soils. With $R$. palustris these soils showed an increase in nitrifying capacity from weeks 4 to 6 , followed by a small decrease from weeks 6 to 10 , resulting in a return to the nitrifying capacity of week 4 . In contrast, the waterlogged soils planted with $R$. thyrsiflorus, maintained a constant nitrifying capacity from weeks 4 to 6 followed by a major decrease, so that in week 10 the nitrifying capacity was approximately $10 \%$ of that in week 4 .

The nitrate reductase activity (Fig. 5) in the leaves seemed to be a good reflection of the $\mathrm{NH}_{4}^{+}: \mathrm{NO}_{3}^{-}$ratio in the soil, as presented in Table 1. In all pots where $\mathrm{NO}_{3}^{-}$was an important part of the soil mineral $\mathrm{N}$ nitrate reductase activity was relatively high. The only exceptions were the $R$. palustris plants in waterlogged soils after 10 
Fig. 3 Mean dry-matter accumulation of shoots and roots of Rumex thyrsiflorus and $R$. palustris in well drained soils (open bars) and waterlogged soils (grey bars). Values are $\pm \mathrm{SD}, n=4-5$. In week 4 the bars indicating the drained soils also represent the starting point of the waterlogged series. Different letters above the bars indicate significant differences between soils or sampling times $(P \leq 0.05)$
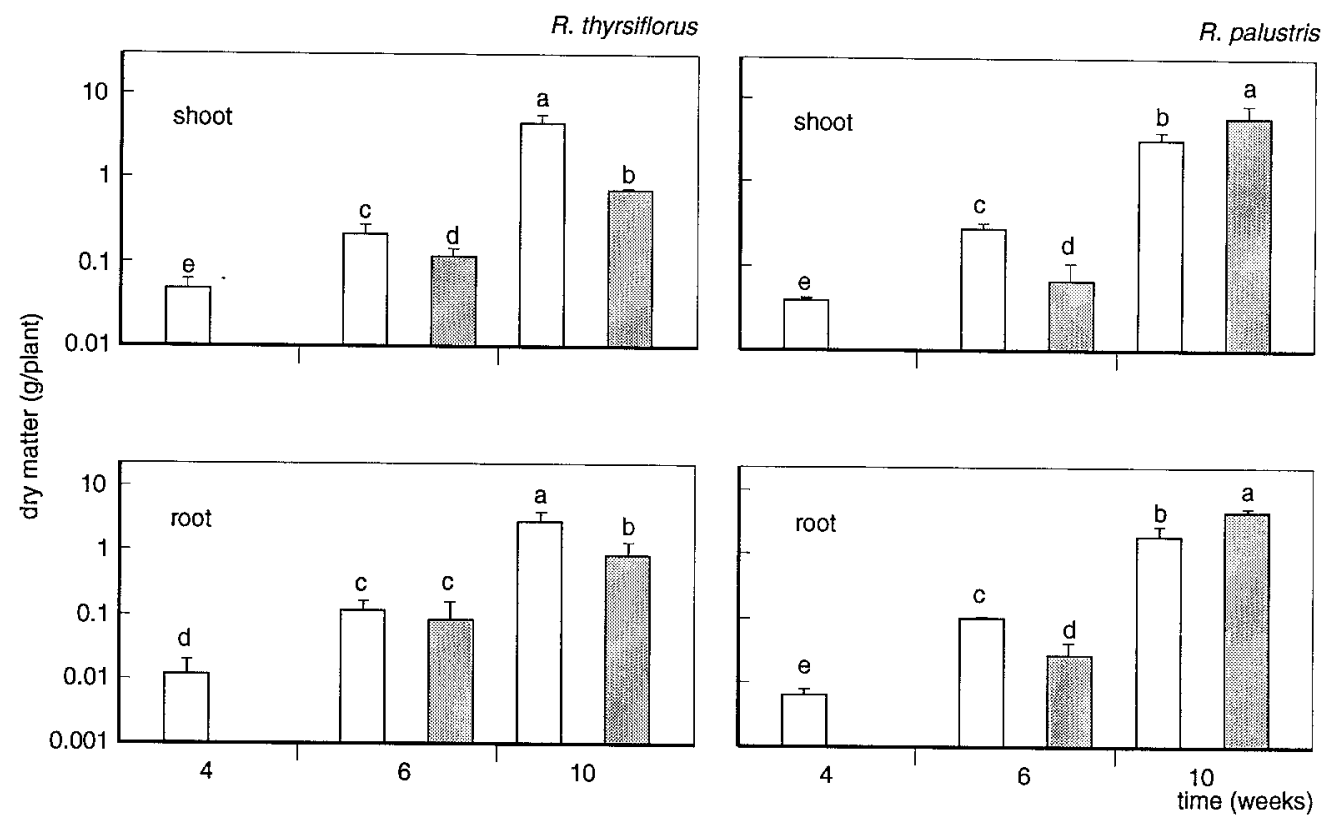

weeks, which combined high nitrate reductase activity with a high $\mathrm{NH}_{4}^{+}: \mathrm{NO}_{3}^{-}$ratio.

\section{Discussion}

The first experiment showed that the nitrate reductase activity of leaves of both plant species was a good indication of $\mathrm{NO}_{3}^{-}$availability in the soil throughout a large part of the day and night. This affirms the higher nitrate reductase activity in leaves of plants supplied with $\mathrm{NO}_{3}^{-}$ compared to plants supplied only with $\mathrm{NH}_{4}^{+}$, as reported before (Barro et al. 1991; Langelaan and Troelstra 1992).

It is very likely that nitrification took place in the waterlogged soils with $R$. palustris. According to other studies the measured redox potential was high enough to expect the presence of $\mathrm{O}_{2}$ (Pearsall and Mortimer 1939; Turner and Patrick 1968; Watanabe and Furusaka 1980), which is needed for the nitrification process. Also, the ni- trifying capacity remained at a high level after waterlogging. The relatively low mineral $\mathrm{N}$ content of the waterlogged soils planted with $R$. palustris (Table 1) can be explained by the large $\mathrm{N}$ accumulation in the biomass (Fig. 3). Although no precise $\mathrm{N}$ balance could be calculated, an estimate of the $\mathrm{N}$ retrieved was made. On the basis of previous experiments, the $\mathrm{N}$ content of the plants was assumed to be $1500 \mu \mathrm{mol}$ per $\mathrm{g}$ dry weight. The estimates of $\mathrm{N}$ incorporated in the plant biomass plus mineral $\mathrm{N}$ in the soil were 14.4 and $15.0 \mathrm{mmol}$ for the well drained and waterlogged pots, respectively, planted with $R$. thyrsiflorus and 18.1 and $16.4 \mathrm{mmol}$ for those planted with $R$. palustris. For $R$. thyrsiflorus, this accounted for 72 and $75 \%$ of the total of $20 \mathrm{mmol} \mathrm{N}$ applied to each pot in well drained and waterlogged soils, respectively. For $R$. palustris, this accounted for $91 \%$ in the well drained pots and $82 \%$ in the waterlogged pots. Since $N$ recoveries in the waterlogged and well drained pots were high and almost equal, $\mathrm{N}$ losses as a result of $\mathrm{NO}_{3}^{-}$reduction or immobilization could not have been very high, in contrast to
Table 1 Mean $\mathrm{NH}_{4}^{+}$and $\mathrm{NO}_{3}^{-}$concentrations ( $\mu \mathrm{mol} \mathrm{g}^{-1}$ dry weight) in drained $(D)$ and waterlogged (W) soils, with either Rumex thyrsiflorus or $R$. palustris ( $\pm 1 \mathrm{SD}, n=4-5$ ). Waterlogging started in week 4 . The values of the drained soils in week 4 also represent the starting point of the waterlogged series. Different letters indicate significant differences between soil or sampling times within one species $(P \leq 0.05)$

\begin{tabular}{|c|c|c|c|c|}
\hline $\begin{array}{l}\text { Week } \\
\text { number }\end{array}$ & $\begin{array}{l}\text { Soil } \\
\text { type }\end{array}$ & $\mathrm{NH}_{4}^{+}$ & $\mathrm{NO}_{3}^{-}$ & Ratio $\mathrm{NH}_{4}^{+}: \mathrm{NO}_{3}^{-}$ \\
\hline \multicolumn{5}{|c|}{$R$. thyrsiflorus } \\
\hline 4 & $\mathrm{D}$ & $0.11 \pm 0.03 a$ & $1.17 \pm 0.29 b$ & $0.09 \pm$ \\
\hline \multirow[t]{2}{*}{6} & $\mathrm{D}$ & $1.38 \pm 0.60 \mathrm{~b}$ & $5.49 \pm 1.38 \mathrm{a}$ & $0.25 \pm 0.07 \mathrm{c}$ \\
\hline & W & $3.94 \pm 0.92 c$ & $0.29 \pm 0.25 \mathrm{c}$ & $144 \pm 277 \mathrm{~b}$ \\
\hline \multirow[t]{2}{*}{10} & $\mathrm{D}$ & $2.30 \pm 2.47 b c$ & $5.41 \pm 8.59 \mathrm{ab}$ & $0.57 \pm \quad 1.03 \mathrm{~cd}$ \\
\hline & W & $21.02 \pm 4.46 \mathrm{~d}$ & $0.004 \pm 0.004 \mathrm{~d}$ & $4832 \pm 2556 a$ \\
\hline \multicolumn{5}{|c|}{ R. palustris } \\
\hline 4 & $\mathrm{D}$ & $0.06 \pm 0.00 \mathrm{~d}$ & $5.13 \pm 0.91 \mathrm{c}$ & $0.01 \pm$ \\
\hline \multirow[t]{2}{*}{6} & $\mathrm{D}$ & $0.33 \pm 0.37 \mathrm{c}$ & $11.8 \pm 2.13 b$ & $0.05 \pm$ \\
\hline & W & $6.06 \pm 0.73 a$ & $3.79 \pm 0.11 \mathrm{~d}$ & $1.68 \pm$ \\
\hline \multirow[t]{2}{*}{10} & $\mathrm{D}$ & $1.72 \pm 2.38 b c$ & $16.7 \pm 4.76 \mathrm{a}$ & $0.11 \pm$ \\
\hline & W & $3.96 \pm 3.53 b c$ & $0.06 \pm 0.05 \mathrm{e}$ & $46.7 \pm$ \\
\hline
\end{tabular}




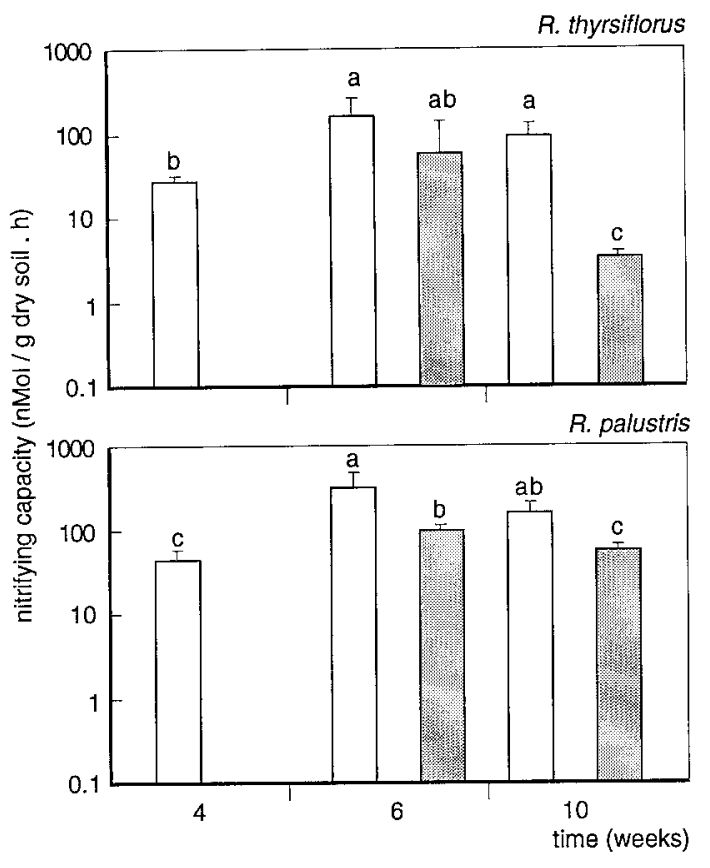

Fig. 4 Mean nitrifying capacity of drained soils (open bars) and waterlogged soils (grey bars) planted with either Rumex thyrsiflorus or $R$. palustris. For other explanations see Fig. 3

a previous experiment (Engelaar et al. 1991). The high nitrate reductase activity of $R$. Palustris grown in waterlogged soils (Fig. 5) indicates that at least a part of this $\mathrm{N}$ was taken up as $\mathrm{NO}_{3}^{-}$(Langelaan and Troelstra 1992). The nitrate reductase activity in both the waterlogged and the well drained $R$. palustris plants was higher than the basal level found for $\mathrm{NH}_{4}^{+}$nutrition (Figs. 1, 5). The exception of the high nitrate reduction activity in combination with a high $\mathrm{NH}_{4}^{+}: \mathrm{NO}_{3}^{-}$ratio observed for the waterlogged soils planted with $R$. palustris can then be explained by a high rate of $\mathrm{NO}_{3}^{-}$uptake by the plant, possibly in combination with some $\mathrm{NO}_{3}^{-}$reduction in anoxic sites in the soil.

No nitrification took place in the waterlogged soil planted with $R$. thyrsiflorus. The applied $\mathrm{NH}_{4}^{+}$accumulated in the soil (Table 1) and the nitrifying capacity decreased drastically (Fig. 4). The relatively low nitrate reductase activity of plants grown on waterlogged soil, approximately basal level, indicated that $\mathrm{N}$ had predominantly been taken up as $\mathrm{NH}_{4}^{+}$by the plant (Figs. 1, 5). In contrast, nitrification did occur in the well drained soil where the nitrifying capacity increased during the experiment (Fig. 4) and $\mathrm{NO}_{3}^{-}$was produced. In these pots the nitrate reductase activity was significantly higher, indicating that $\mathrm{NO}_{3}^{-}$was available to the plants. Thus inhibition of nitrification in the presence of $R$. thyrsiflorus was a direct result of the waterlogging treatment, which resulted in anoxia, as illustrated by the low redox potential (Fig. 2). The redox potential was below the critical value for the presence of $\mathrm{O}_{2}$ (Turner and Patrick 1968). It remained constant at $250 \mathrm{mV}$, a value at which $\mathrm{NO}_{3}^{-}$usually becomes reduced (Patrick 1960). The stabilization at

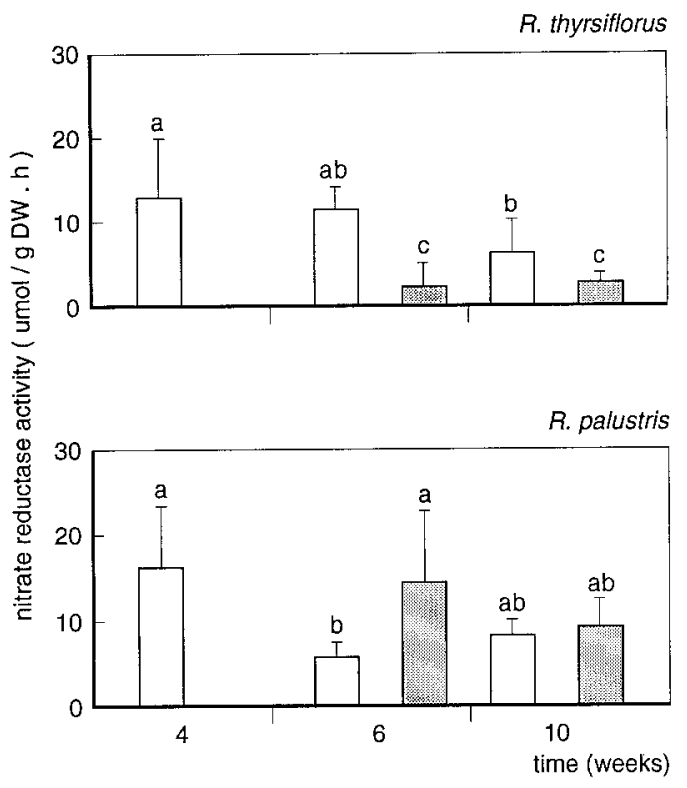

Fig. 5 Mean nitrate reductase activity in leaves of Rumex thyrsiflorus and $R$. palustris grown on drained soils (open bars) and waterlogged soils (grey bars). $D W$ dry weight; for other explanations see Fig. 3

this redox level might have been the result of a poising effect by $\mathrm{NO}_{3}^{-}$that was already present at the start of waterlogging (Gambrell and Patrick 1978) or by a slow downward diffusion of small amounts of $\mathrm{NO}_{3}^{-}$from the better oxygenated water layer.

In contrast to our previous experiment (Engelaar et al. 1991) no negative correlations were found between the plant biomass and the nitrifying capacity of the soil, excluding the possibility that soluble root exudates may have affected nitrification. In fact, in the waterlogged pots of $R$. palustris in week 10 , nitrifying capacity was positively correlated shoot biomass $(P \leq 0.01)$. This might have been the result of a larger radial $\mathrm{O}_{2}$ loss, and subsequent stimulation of the nitrifying capacity, by a larger plant. Still, there seemed to be a tendency for the nitrifying capacity to show a slight decrease, even in those treatments where sufficient $\mathrm{O}_{2}$ and $\mathrm{NH}_{4}^{+}$were available, in the well drained series of both species and the waterlogged series of $R$. palustris. This effect was also evident in previous experiments (unpublished data) and cannot yet be explained. It is highly unlikely to be the result of an $\mathrm{NH}_{4}^{+}$limitation since no negative correlation with the plant biomass nor any positive correlation with the $\mathrm{NH}_{4}^{+}$ content of the soil was found. Compared to the effects of waterlogging on $R$. thyrsiflorus, inhibition of nitrification in the presence of $R$. palustris was only of minor importance.

We therefore conclude that waterlogging in the presence of $R$. thyrsiflorus resulted in anoxia, a depressed nitrification capacity, and an accumulation of $\mathrm{NH}_{4}^{+}$in the soil. When the soil remained aerated through radial $\mathrm{O}_{2}$ loss, as happened with $R$. palustris, the redox potential and nitrifying capacity of the soil remained at a far 
higher level. Since the possibility of an $\mathrm{NH}_{4}^{+}$limitation can be excluded, the three basic conditions needed for nitrification, $\mathrm{O}_{2}, \mathrm{NH}_{4}^{+}$, and a potentially active nitrifying population, were all present in these soils. That nitrification actually took place in waterlogged soils planted with $R$. palustris was demonstrated by the high nitrate reductase activities in the leaves of these plants, which indicated uptake of $\mathrm{NO}_{3}^{-}$.

These results, together with those reported previously (Engelaar et al. 1991), indicate that nitrification can be maintained in the rhizosphere of a plant with aerenchymatous roots under waterlogged conditions, but only when sufficient $\mathrm{NH}_{4}^{+}$is present to support both the plant and the total microbial population.

Acknowledgements We thank Maarten van $\mathrm{Hal}$ for his contribution to this experiment.

\section{References}

Amberger A (1986) Potentials of nitrification inhibitors in modern $\mathrm{N}$-fertilizer management. $\mathrm{Z}$ Pflanzenernaehr Bodenkd 149:469-484

Armstrong W (1979) Aeration in higher plants. Adv Bot Res $7: 225-332$

Barro F, Fontes AG, Maldonado JM (1991) Organic nitrogen content and nitrate reductase activities in tritordeum and wheat grown under nitrate or ammonium. Plant Soil 135:251-256

Belser LW (1979) Population ecology of nitrifying bacteria. Annu Rev Microbiol 33:309-333

Beevers J, Hageman RH (1969) Nitrate reduction in higher plants. Annu Rev Plant Physiol 20:495-522

Blom CWPM, Bögemann GM, Laan P, Sman AJM van der, Steeg HM van de, Voesenek LACJ (1990) Adaptations to flooding in plants from river areas. Aquat Bot 38:29-47

Bogner W (1968) Experimentelle Prüfung von Waldbodenpflanzen auf ihre Ansprüche an die Form der Stickstoffernährung. Mitt Forstl Standortsk Forstpflanzenzücht 18:3-45

Both GJ, Gerards S, Laanbroek HJ (1992) The occurrence of chemolitho-autotrophic nitrifyers in water-saturated grassland soil. Microb Ecol 23:15-26

Ellenberg H (1977) Stickstoff als Standortfaktor, insbesondere für mitteleuropäische Pflanzengesellschaften. Oecol Plant 12:1-22

Engelaar WMHG, Bodelier PLE, Laanbroek HJ, Blom CWPM (1991) Nitrication in the rhizosphere of a flooding-resistant and a flooding-non-resistant Rumex species under drained and waterlogged conditions. FEMS Microbiol Ecol 86:33-42
Gambrell RP, Patrick WH Jr (1978) Chemical and microbiological properties of anaerobic soils and sediments. In: Hook DD, Crawford RMM (eds) Plant life in anaerobic environments. Ann Arbor Sci Publ, Ann Arbor, pp 375-423

Gigon A, Rorison IH (1972) The response of some ecologically distinct plant species to nitrate- and to ammonium-nitrogen. J Ecol 60:93-102

Hoagland DR, Arnon DI (1950) The water-culture method for growing plants without soil. Circ Calif Agric Exp Stn 347, Univ Calif, Berkeley

Jaworski EG (1971) Nitrate reductase assay in intact plant tissues. Biochem Biophys Res Commun 43:1274-1279

Justin SHFW, Armstrong W (1987) The anatomical characteristics of roots and plant response to soil flooding. New Phytol $106: 465-495$

Laan P, Berrevoets MJ, Lythe S, Armstrong W, Blom CWPM (1989 a) Root morphology and aerenchyma formation as indicators of the flood-tolerance of Rumex species. $\mathbf{J}$ Ecol $77: 693-703$

Laan P, Smolders A, Blom CWPM, Armstrong W (1989b) The realtive roles of internal aeration, radial oxygen losses, iron exclusion and nutrient balances in flood-tolerance of Rumex species. Acta Bot Neerl 38:131-145

Laanbroek JH (1990) Bacterial cycling of minerals that affect plant growth in waterlogged soils: a review. Aquat Bot 38:109-125

Langelaan JG, Troelstra SR (1992) Growth, chemical composition, and nitrate reductase activity of Rumex species in relation to form and level of N supply. Plant Soil 145:215-229

Patrick WH Jr (1960) Nitrate reduction in a submerged soil as affected by redox potential. Trans 7 th Int Congr Soil Sci 2:494-500

Pearsall WH, Mortimer CH (1939). Oxidation-reduction potentials in waterlogged soils, natural waters and muds. $\mathrm{J}$ Ecol 27: $485-501$

Ponnamperuma FN (1984) Effects of flooding on soils. In: Kozlowski (ed) Flooding and plant growth. Academic Press, New York, pp 10-45

Sokal RR, Rohlf FJ (1981) Biometry. WH Freeman, San Francisco

Turner FT, Patrick WH Jr (1968) Chemical changes in waterlogged soils as a result of oxygen depletion. Trans 9th Int Congr Soil Sci 4:53-65

Uhel C, Roumet C, Salsac L (1989) Inducible nitrate reductase of rice plants as a possible indicator for nitrification in waterlogged paddy soils. Plant Soil 116:197-206

Voesenek LACJ, Blom CWPM, Pouwels RHW (1989) Root and shoot development of Rumex species under waterlogged conditions. Can J Bot 67:1865-1869

Watanabe I, Furusaka C (1980) Microbial ecology of flooded rice soils. Adv Microb Ecol 4:125-168

Watson SW, Bock E, Harms H, Koops H-P, Hooper A (1989) Nitrifying bacteria. In: Stoley CJT, Bryant MP, Pfennig N, Helt JG (eds) Bergey's manual of systematic bacteriology, vol 3. Williams and Wilkins, Baltimore, Md, pp 1808-1834 